\title{
DEMAND FOR IMPROVED SOLID WASTE SERVICES IN JIMMA TOWN, ETHIOPIA: EVIDENCE FROM HOUSEHOLD SURVEY DATA
}

\author{
Degnet Abebaw' \\ and \\ Maru Ayenew ${ }^{2}$
}

\begin{abstract}
The main purpose of this study has been to measure the influence of socioeconomic, demographic and location characteristics on households' willingness to pay for improvement of solid waste services. The data for the study was obtained from a random sample of 200 households in Jimma town. Descriptive analysis of the data reveals that while some households are not willing to pay, others are interested to contribute either in labour, in cash or both for improvements in solid waste management services in Jimma town. Estimation results of a multinomial logit model indicate that these choices are influenced by a certain combination of family size, education and age of the household, years of schooling of children or family member, wealth, life-style and location of the dwelling unit. The study concludes with some policy implications for improved solid waste management services in Jimma town.
\end{abstract}

Keywords: Solid waste management, households' willingness to pay, multinomial logit, Jimma, Ethiopia

1 Address of Corresponding Author:

Ethiopian Economic Association/Ethiopian Economic Policy Research Institute, P. O. Box 34282, Tel.: 251114-162121, Fax: 251-114-160967, E-mail: degnet2003@yahoo.com

22 maryayenew@yahoo.com

\section{Acknowlodgement}

We acknowledge the financial support given by the Jimma University College of Agriculture to conduct the study. 
1. Introduction

Public access to reliable solid waste services is an essential ingredient for improved human health, safe environment and sustainable development (Ahmed and Ali, 2004; Doan, 1998; Altaf and Deshazo, 1996). Solid waste and sanitation services in many developing countries, however, remain unsatisfactory and erratic (Lall et al. 2004; Temesgen and Legesse, 2005; Altaf and Deshazo, 1996). According to CointreauLevine (1994), around $30-50 \%$ of residents in most cities in developing countries do not get proper solid waste management services and most of the time their disposal practices are unsafe. In the literature on solid waste issues, supply side constraints are among the main reasons for the insufficient supply of solid waste management services such as collection, transportation and disposal. In fact, many municipal governments of developing countries, including that of Ethiopia, lack adequate physical and financial resources to generate optimal amount of public services for their inhabitants (Thapa, 1998; Altaf and Deshazo, 1996; Lall ot al., 2004).

Reviewing the literature on solid waste management services for Ethiopia one finds that these services are poor and inefficient. As a result, the majority of inhabitants in most towns in the country often use unsafe solid waste disposal practices, such as open dumping, burning, burying and so on. For instance, according to Birke's (1999) study of the municipal solid waste management practices of 15 regional cities of Ethiopia, a controlled solid waste disposal is practiced in only 2 of them. The study of Bonga town in southwestern Ethiopia by Temesgen and Legesse (2005) also shows the widespread lack of proper municipal solid waste services. Similarly, in Jimma town, where we carried out this study, solid waste service is still rudimentary and inefficient. During writing this paper, the town had only one dump truck for solid waste collection and disposal services for the entire population of over 138,070 people.

Previous studies elsewhere clearly pointed out that the participation of the local population in the formulation and implementation of urban infrastructure projects could help raise the supply of solid waste services in developing countries (Lall et al., 2004; Altaf and Deshazo; 1996). In this respect, a better understanding of residents' preferences and willingness to pay for improved delivery of non-market goods would pave way for entrepreneurs and small-enterprises to contract with residents to deliver the service at a lowest possible cost (Thapa, 1998). In fact, the involvement of the private sector in the delivery of waste management services would also ease government's budgetary pressure and enable local municipality to concentrate on other development activities (Ahmed and Ali, 2004; Obirih-Opareh and Post, 2002). 
In this paper, we hypothesize and explain that a household's WTP for improved solid waste management practices is determined by his/her socioeconomic, demographic and location characteristics. In the estimations, we also focus on how the impacts of these factors vary between the types of payment required and discuss its implications for mobilizing local resources for household solid waste management in Jimma town. This study was carried out in Jimma town using a random sample of 200 households. Several factors contributed to the choice of Jimma town for this study. First. Jimma town is the biggest town in population size in southwest Ethiopia. Second, available evidence (Kebede and Mirgissa, 1999) reveals that the supply of most public services such as water, sanitation, solid waste are inadequate and are major threats to human health and environmental conditions. For instance, about $59.49 \%, 54.45 \%, 29.5 \%$, and $92.22 \%$ of the total household population of Jimma do not have access, respectively, to private house, to tap water, to private toilet and to a private telephone set (CSA, 1994). Third, as with most municipalities in Ethiopia, the municipality of Jimma town has limited fiscal, human and physical resources to expand and optimally provide its services to a rapidly growing number of inhabitants in the town. As one official of the municipality (Abay, 2000, personal communication) vividly reported to us, improvements in the delivery of solid waste services in Jimma town remains one of the top priorities of policy makers and local administrators. In view of these and similar other concerns, findings of this study would be useful to policy makers and public administrators who seek to know the potential of residents to participate in and benefit from improved provision of sanitation and solid waste services.

The paper is organized into five sections. Section 2 describes the study areas and the dataset. Section 3 defines the theoretical and empirical research methods of the study. The results and discussion of the paper are presented in Section 4 and the paper concludes in Section 5 .

\section{Study area and data}

Jimma is the biggest town in the southwestern Ethiopia. It is located at 335 kilometers away from Addis Ababa with a geographic location of $7^{\circ} 40^{\prime} \mathrm{N}$ latitude and $36^{\circ} 60^{\prime} \mathrm{E}$ longitudes. The town occupies a total area of nearly 4623 hectares, of which about $26 \%$ is a residential area. Its mean annual rainfall varies between $450-1800$ millimeters. Jimma has a warm and humid climate with daily average temperature of $20{ }^{\circ} \mathrm{C}$ and mean annual rainfall varying between 1450 and 1800 millimeters. During the field survey of this study, Jimma town had 20 administrative Kebeles.

Based on a sample frame of the total administrative units in the town, a total of four Kebeles were randomly chosen for the study: Next, a random sample of 200 
households was selected from these Kebeles for detailed household interviews. The survey was carried out from August to September 2000. Semi-structured questionnaires were used for personal interviews by four trained enumerators. The questionnaires were pre-tested in the same site. The enumerators were trained both in the class and field conditions on how to administer the survey questionnaires to the respondents and how to collect the necessary data for the study. Data were collected on a wide range of topics such as personal and household characteristics, income, wealth, access to infrastructure and attitudes towards environment. A special section of the questionnaires elicited households' current solid waste management practices and also asked their willingness to pay for improved municipal provision of solid waste management services. Secondary data were collected from various publications and census reports. Furthermore, key informant discussions were carried out to get feedback about the status of various public services provided by the municipality.

\section{Methods}

Revealed preference, and stated preference methods are the two main approaches for assigning economic value for benefits of environmental goods and services (Young, 2005). Revealed preference methods are based on how individuals actually behave whereas stated preference methods use data on what individuals say they would behave contingent on a certain hypothetical market or program. However, at present it is very difficult to infer economic and environmental benefits of solid waste management services based on existing markets because these services are often under-priced or non/priced in most developing countries (Anaman and Jair, 2000 cited in Jin et al., in press). To overcome this difficulty, in this study, we applied a stated preference method to elicit consumers' preferences for solid waste services, ex ante, based on their willingness to pay for a hypothetical change.

\subsection{Contingent valuation}

Contingent valuation method (CVM) is a widely used stated preference method for estimating public values of environmental goods and services to society (Hanley and Spash, 1993). In other words, CVM is an important tool for researchers to inform policy makers about public values of environmental goods and services for which market prices do not exist or are not able to capture their social value. It enables them to put monitory values on products and services for which there is a market failure. A literature cited in Cameron et al. (2002) shows that contingent valuation (CV) estimates correspond in $75-90 \%$ of the cases to economic agents' actual or revealed preference values, indicating that CVM approximates reality fairly well. In 
1993, the National Oceanic and Atmospheric Administration (NOAA) Blue Ribbon Panel reviewed the $C V$ literature available at the time, and concluded that $C V$ studies can yield estimates reliable enough to be a good starting point for natural resource policy making and damage assessment (Carlson, 1997; Portney, 1994).

$\mathrm{CV}$ is a direct information elicitation technique using a survey of individuals to estimate what they would be willingness to pay (WTP) for an improvement of the quality of services or products from a status quo, or the minimum amount of compensation they would be willing to accept (WTA) for a deterioration from a status quo (Echenssah et al., 1997). Stated in other words, WTP replies provide the Hicksian compensating variation as it leaves the respondent at the same utility level after realization of proposed welfare-improving programs and resulting expressed WTP. On the other hand, WTA replies give information about compensating variation for welfare-decreasing moves (Hanley and Spash, 1993). In the present case study, we applied WTP format since the hypothetical scenario would create a higher wellbeing to the target population of the study.

CVM has been used extensively in the USA, Europe and Australia (for comprehensive review of CVM applications, see Bateman et al., 1999). The first application of CVM was to determine the value to hunters and wilderness lovers of a particular recreational area (Davis, 1963 cited in Portney, 1994). Application of CV in developing countries has remained few and far apart for a long period. However, recent evidence shows that its applications are also expanding to developing countries (Whittington, 1998). Some notable examples are the study by Asrat et al. (2004) to elicit farmers' WTP for certain soil conservation practices in southeastern highlands of Ethiopia, Altaf and Deshazo (1996) to infer consumers' demand for solid waste management practices in Pakistan, Lura et al. (1999) to estimate households' willingness to pay for domestic water services in the Philippines, Echessah et al. (1997) to determine factors influencing households' WTP for tsetse control in Kenya.

A CV questionnaire is expected to be composed of the following key ingredients. Firstly, the survey questionnaire must contain and clearly describe a scenario or proposed (hypothetical or real) program to which respondents are asked to value or vote upon. The scenario is expected to provide the respondent a clear picture of the 'good' that they are being asked to value. Secondly, it must lay out the question format and specify the mechanism by which the respondents would be willing to pay for a welfare-improving program or be willing to accept compensation for a welfare decreasing program. To be useful a payment vehicle must be realistic and free of bias (Hanley and Spash, 1993). The CV question may follow an open-ended question, a bidding game and a referendum format. Finally, a CV survey should elicit information on respondents' socioeconomic and other characteristics. 
In this study we used a referendum format to elicit if the respondents vote yes/no for a CV proposal that asks them to pay for a hypothetical policy scenario to improve solid waste management services in Jimma town. According to Hanemann (1984), the respondents' yes/no answers are interpreted as instances of utility maximization. In other words, an individual's 'yes' or 'no' response is assumed to depend on whether the difference in indirect utility between WTP and lack of WTP is positive (Cameron et al., 2002). Thus, consider the following indirect utility function for a representative individual household:

$$
V(Y, P, \mathrm{Z}, \mathrm{Q})
$$

where, $Y$ is an individual's income; $P$ is a vector of prices of all goods and services except solid waste; $Z$ is an individual's socioeconomic, demographic, locational and institutional characteristics and $Q$ is the current level of solid waste services received by the individual household. Suppose now a local policy that improves existing solid waste management services available to all inhabitants. From this it follows that the welfare measure involved is given as follows:

$$
V\left(Y-W T P, P, Z, Q_{1}\right)=V\left(Y, P, Z, Q_{0}\right)
$$

where, WTP is a household's willingness to pay to secure a welfare gain from an improved change in solid waste service, that is the change from $Q_{0}$ to $Q_{1}$. The amount of this change corresponds to the Hicksian compensation variation for the proposed policy.

\subsection{Empirical model and hypotheses}

In this section we outline the econometric model that is proposed to estimate the impacts of hypothesized explanatory variables on households' WTP responses for a hypothetical CV program. More particularly, a multinomial logit (MNL) model has been used to estimate the probability of an individual's WTP for improvements in solid waste management services. As described above, respondents provided their answers to whether or not they would be willing to raise only cash, only labour, both cash and labour or remain unwilling to pay any contribution for implementing the $\mathrm{CV}$ program. ${ }^{3}$ For econometric estimation these responses are coded as follows:

\footnotetext{
${ }^{3}$ The choice set for the econometric estimation of the MNL model should be mutually exclusive and exhaustive (Train, 2003). To assure this outcome, we pose a question to our respondents in such a way that it yields either of the following outcomes: WTP in only labour, only cash, both labour and cash or not WTP.
} 


\section{$P=\left\{\begin{array}{l}0 \text { if a respondent is not WTP } \\ 1 \text { if a respondent is WTP only labour } \\ 2 \text { if a respondent is WTP only cash } \\ 3 \text { if a respondent is WTP both cash and labour }\end{array}\right.$}

In choosing among these options, an individual is assumed to maximize his/her expected utility subject to time and budget constraints. An individual's utility function from using alternative payment vehicle by which he would be WTP for a proposed CV scenario is represented by a random utility model (RUM) (see MacFadden, 1978, 1981), where:

$$
U(\text { choice } j \text { for household } i)=U_{i j}=V_{i j}+\varepsilon_{i j}
$$

where, $U_{\eta}$ is the overall utility, $V_{i j}$ is an indirect utility function and $\varepsilon_{i j}$ is a stochastic component, which is again assumed to be identically and independently distributed across alternatives.

In the above specification (equation 3 ) it is assumed that given $J$ bid vehicles for choice, an individual selects the one that brings the highest indirect (expected) utility, $V_{y}$. In other words, an individual $i$ will select bid vehicle $j$ if $U_{i j}>U_{i k}, \forall k \neq j$.

The measured component $V_{i j}$ is linearly related to the individuals' personal, sociodemographic and economic characteristics, $X_{i j}$, which can be specified as follows:

$$
V_{y}=\beta_{1} X_{y}
$$

where, $\beta$, is a vector of regression coefficients, which measures the impact of, $X_{i j}$, on the probability of choosing bid vehicle $j$. Thus, the probability that an individual $i$ choosing payment vehicle $j$ out of $J$ alternatives can be represented by the following equation:

$$
P_{i y}=\frac{\exp \left(\beta_{j} X_{y}\right)}{\sum_{k=1}^{j} \exp \left(\beta_{k} X_{i k}\right)}
$$


where, $\beta$, and $\beta_{k}$ measure impact of observable characteristics of the respondent on the probability of choosing payment vehicles $j$ and $k$, respectively. In the MNL model, only $J-1$ of the parameters can be recovered (Haab and McConnel, 2002). For instance, with four categories of the dependent variable mentioned above for the present study, there will be three non-redundant logits. Hence, in the econometric specification of the MNL model it is a common practice to normalize equation (5) by one of the response categories and by constraining $\beta_{j}=0 .{ }^{4}$ Accordingly, the MNL model can be re-specified as follows:

$$
P_{y}=\frac{\exp \left(\beta, X_{1}\right)}{1+\sum_{k=0}^{J-1} \exp \left(\beta_{k} X_{1}\right)}
$$

The coefficients of explanatory variables on the omitted or base category are assumed to be zero. With this assumption, the probability that a base category will be chosen can be obtained by using the following equation:

$$
P_{i j}=\frac{1}{1+\sum_{k=0}^{J-1} \exp \left(\beta, X_{i}\right)}
$$

The log likelihood function of the MNL model can be calculated as follows (Greene, 2000):

$$
\left.\ln L=\sum_{i=1}^{n} \sum_{k=0}^{J} d_{i j} \ln \operatorname{Prob}\left(Y_{i}=J\right)\right)
$$

The sign and significance of an explanatory variable on the dependent variable should always be interpreted relative to the chosen base category. Another point to note here is that direct interpretation of the estimated coefficients of the MNL model is difficult because the MNL model is non-linear in nature (Aldrich and Nelson, 1984). One means of overcoming this problem is use the relative risk ratios ${ }^{5}$ (RRR) of the explanatory variables.

\footnotetext{
- In the econometric estimation of the MNL model, the most frequent response is usually taken to be the reference category (Long and Freese, 2001). However, the choice of which category is chosen as the reference category does not influence the estimation results, it only affects the way parameter estimates are to be interpreted.

${ }^{5} \mathrm{RRR}$ is defined as $\exp (\beta)$, which indicates the ratio of probability of occurrence of a current category to the probability of occurrence of a base category as a result of one unit change in the corresponding explanatory variable.
} 
The selection of explanatory variables $X$ to be included in the MNL model has been guided by the literature on economics of solid waste and field-setting of the study area. Detailed description and summary statistics of the variables used in the study are presented in Table 1. Below we discuss the expected influence of various explanatory variables on households' willingness to pay for improvements in solid waste services.

\section{Table 1: Definition and summary statistics of the dependent and explanatory} variables

\begin{tabular}{|c|c|c|}
\hline Variables, and measurements & Mean or percent & Std. Dev. \\
\hline \multicolumn{3}{|l|}{ The dependent variable categories $(\%)$} \\
\hline Not willing to pay in any form (0) & $14.00 \%$ & \\
\hline WTP labour-only (1) & $42.50 \%$ & \\
\hline WTP cash-only (2) & $11.00 \%$ & \\
\hline WTP both cash and labour (3) & $32.50 \%$ & \\
\hline Explanatory variables & & - \\
\hline HHAGE & 45.63 & 12.97 \\
\hline HHSZ & 5.06 & 2.193 \\
\hline GEND & $65 \%$ & \\
\hline EDUC1 & 7.62 & 4.786 \\
\hline EDUC2 - & 12.46 & 4.38 \\
\hline INCOM & 127.80 & 133.55 \\
\hline TRAD & $17 \%$ & \\
\hline WEALTH & $12 \%$ & \\
\hline TENUR & $44 \%$ & \\
\hline SHOUS & 19.04 & 11.54 \\
\hline ROAD & 3.56 & 3.37 \\
\hline
\end{tabular}

Source: Own survey, 2000.

Age of household head (HHAGE): according to Karppinen and Hanninen (2000), and Vanslembrouk et al. (2002), younger people are much more concerned about and are more interested to support the conservation of natural resources and environment than older ones. Likewise, a study by Altaf and Deshazo (1996) finds that willingness to pay for improved solid waste management services is strongly and negatively influenced by the age of the household head. In a similar vein, in this study 
age of household head is assumed to influence WTP for the proposed solid waste management program negatively. This variable was measured by number of years of the household head's age since birth.

Household size (HHSZ): it is expected that household size, measured by number of persons in the family, is directly associated with willingness to pay for improved solid waste management services.

Gender of household head (GEND): gender of head of household head is also one factor often considered in the study of household behavior with regard to conservation of natural resources and environmental quality. In this regard, existing studies show that females are more likely to reveal pro-environmental behavior than males (Steel et al., 1994). In the context of Ethiopia, mostly women and children carry out the majority of domestic chores including the disposal of solid waste. As such, in this study we anticipate that female-headed households are more likely to pay for improved solid waste management services than their male-headed counter-parts. This is a dummy variable with a value of 1 if male, and 0 otherwise.

Education of household head (EDUC1): education is a key instrument by which citizens gain knowledge of socioeconomic and environmental impacts of their daily decisions. In so doing, economic theory postulates that education enables an economic agent to make a better decision(s). Steel et al. (1994) assert that education promotes pro-environmental attitudes and behavior. In the solid waste management literature, various empirical studies have pointed out that education contributes to investment on environmental quality. For instance, a study by Lall et al. (2004) found out that years of schooling of head of household increases willingness to pay for improved urban services provision in Bangalor, India. Furthermore, a study by Lauria et al. (1999) for the Philippines indicates that education of the household head increases willingness to pay for improved sanitation services. In this study, we also hypothesize that years of schooling of the household head has a direct relationship with WTP for improved solid waste management services.

Education of children (EDUC2): in the literature, no significant effort has been given to test the impact of child education on their parents' attitude towards nature and environmental resources. However, children have a direct exposure to physical neighborhood conditions and this allows them to understand the costs and benefits of keeping their environment clean. In this respect, child education is one means of increasing their awareness to and conservation of environmental amenities. As such, in this study we hypothesize that parents' willingness to pay for improved delivery of solid waste services is directly associated with years of schooling of their children. 
Animal farming (TRAD): whether a household rears cattle is anticipated to influence his/her WTP. This variable takes on two values, 1 if the household is involved in animal husbandry and 0 otherwise.

Ownership of a refrigerator (WEALTH): it is expected that wealth is essential in determining to care for the environment. In this study we use ownership of a refrigerator as a proxy for wealth and expect that is has a positive influence on household WTP for improved solid waste services. Again, this variable is a dummy variable with a value of 1 if the household has a refrigerator and 0 otherwise.

Household income (INCOM): a study by Lauria et al. (1999) for the Philippines finds that income has a significant and positive influence on household willingness to pay for improved sanitation services. In another study (Altaf and Deshazo, 1996) in Pakistan, a significant and positive relationship between income and willingness to pay for improved solid waste management services was found out. Therefore, concurrent to these findings, we anticipate a direct effect of income on willingness to pay for solid waste management services in Jimma town. This variable is a continuous variable representing monthly household income in Ethiopian Birr.

Housing tenure (TENUR): according to Lall et al. (2004), households who own dwelling units are more likely to participate in community based urban service provision programmes than those without. House owners face reduced risk of eviction. As these authors note this enables them to capitalize appreciation in housing values, which results in improved cleanliness of the neighborhood. Drawing on this finding, we anticipate a direct relationship between house ownership and willingness to pay for improved solid waste management services. This variable has two values, namely, 1 for owner occupants and 0 for tenants.

Duration of stay in the house (SHOUS): in this study, number of years of stay in current dwelling unit is expected to have a positive influence on willingness to pay for improved solid waste management services.

Physical distance from road (ROAD): studies (see for e.g. Korfmacher, 1997) indicate that poor roads are one of the main reasons for the inadequacy or lack of solid waste collection systems in urban areas of developing areas. What this means is that the problem of solid waste increases with poor road quality. As such, in this study, it is anticipated that households located farther from a drivable road would be more willing to pay for improved solid waste management services than their colleagues who are found nearer to a drivable road. This variable is measured by walking distance in minutes to nearest main road. 


\section{Results and discussion}

\subsection{Descriptive statistics of the sample households}

Descriptive analysis of socio-economic and demographic data of this study shows various contrasting differences and similarities among the survey household (see Table 1). Of the 200 sample households, $56 \%$ households do not own their own homes and $35.5 \%$ do not have a private toilet. Regarding human capital, about $14 \%$ are illiterate (cannot read and write in any language). Many of them also lack access to public information sources. For instance, around $33 \%$ and $63 \%$ of the survey households, respectively, do not possess a transistor radio and a television set. Access to electricity is also limited and around $16 \%$ of the sample uses crop residue for cooking their meals. The sample households also differ from one another in many ways. The age of household heads range between 18 years and 85 years (mean $=46$ years). On average a household in the sample has 5 household members. Descriptive analysis of the data also suggests the majority of sample households is income-poor and lack access to essential assets. For instance, about $88 \%$ of the households in the sample do not have a refrigerator. Housing is an essential factor for poverty reduction as well as for a better quality of life. However, as the results of this survey indicate, about $56 \%$ of the sample households do not have their own homes. Additionally, the average monthly income of the survey households is low and stands at about 613 Ethiopian Birr per household.

With respect to household access to municipal public utilities, it is estimated that about $74 \%$ of the sample households do not have a tap water source; and nearly $64 \%$ of them do not have a private telephone. In this study, it is also obtained that around $38 \%$ of the respondents do not get private toilet services. Respondents also mention the shortage of household solid waste management facilities. As a result of this, many househoids have used undesirable solid waste disposal practices. For instance, $72(36 \%)$ of the survey respondents dispose their household solid waste indiscriminately to the surrounding environment. Our field observation and discussions with key informants also suggest that the existing waste bins are not emptied on a regular basis.

As shown in Table 1, four types of respondents were distinguished depending on their responses to our valuation question, which reads as follows: "Suppose the local municipality government is to devise a program to improve solid waste management services in Jimma Town, do you contribute any resource to achieve this goal?" Respondents who affirmatively answered our valuation question were asked to specify the form of resource by which they would be willing to pay for the service. As shown in Table 1, the vast majority of the respondents (42.5\%) reported that they 
would like to contribute only labour. Of the total respondents, $14 \%$ declined to pay in any form for the proposed contingent valuation program.

\subsection{Determinants of WTP}

Estimation results of the MNL model are presented in Table 2. To obtain robust variances, we used the Huber and White Sandwich estimators. All explanatory variables were checked for multicollinearity and were found acceptable to be included into the regression model. Econometric analysis of the data was done with done using Stata 8.0 software. In Table 2 , we report the relative risk ratios (RRR), rather than actual coefficients of the independent variables to make the interpretation of our findings easier. An RRR value greater/less than 1 implies that a one unit rise in the independent variable translates into greater/lesser probability of occurrence of that category relative to the reference category. On the other hand, a value of RRR at 1 indicates equal probability of occurrence of the particular category and the reference category.

Table 2: Multinomial logit estimates of households' WTP for improved solid waste management ${ }^{+}$

\begin{tabular}{|c|c|c|c|c|c|c|}
\hline \multirow{2}{*}{$\begin{array}{c}\text { Explanatory } \\
\text { variables }\end{array}$} & \multicolumn{2}{|c|}{ Not willing } & \multicolumn{2}{|c|}{ Only cash } & \multicolumn{2}{|c|}{ Cash and labour } \\
\hline & Estimates & std. errors & Estimates & std. errors & Estimates & std. errors \\
\hline HHAGE & $1.0416^{\circ}$ & 1.75 & 0.9924 & -0.30 & 1.0007 & 0.04 \\
\hline HHSZ & 0.9251 & -0.65 & $0.7906^{\circ}$ & -1.59 & 0.9702 & -0.32 \\
\hline GEND & 0.5512 & -1.01 & 1.5875 & 0.74 & 1.6105 & 1.02 \\
\hline EDUC1 & 1.1448 & 1.97 & 0.9636 & -0.52 & 1.0621 & 1.18 \\
\hline EDUC2 & 1.0851 & 1.39 & $1.1132^{\circ *}$ & 1.68 & $1.1273^{* *}$ & 2.48 \\
\hline INCOM & 0.9996 & -0.63 & 1.0004 & 0.97 & 1.0002 & 0.51 \\
\hline TRAD & $3.1388^{\circ}$ & 2.13 & 0.8173 & -0.27 & 0.5992 & -0.91 \\
\hline WEALTH & 2.7077 & 1.06 & $4.7044^{\circ}$ & 1.75 & $5.0131^{*}$ & 2.23 \\
\hline TENUR & 1.2236 & 0.40 & 1.2921 & 0.46 & 0.6107 & -1.21 \\
\hline SHOUS & 0.9698 & -1.20 & 0.9924 & -0.29 & 1.0014 & 0.07 \\
\hline ROAD & 0.9411 & -0.84 & $1.1249^{\circ}$ & 1.86 & 0.9702 & -0.52 \\
\hline \multicolumn{7}{|l|}{ Intercept } \\
\hline $\begin{array}{l}\text { Number of obs } \\
\text { Wald Chi }{ }^{2} \text { (33) }\end{array}$ & ations & $\begin{array}{l}200 \\
53.07^{\circ}\end{array}$ & $\begin{array}{l}\text { Log-likelih } \\
\text { Pseudo } R^{2}\end{array}$ & $\begin{array}{l}=-223.21 \\
11\end{array}$ & $\vdots$ & \\
\hline
\end{tabular}

Noles: and show statistical significance respectively at the $5 \%$ and $10 \%$ probability levels.

Figures in the parentheses are robust $z$ statistics. ${ }^{+}$Estimates are for RRR. WTP labour-only is the base category.

Source: Authors. 
In the estimation, willing to pay only in labour was taken as the base or reference category, since this is the most frequently reported response to our contingent valuation question. Wald-chi ${ }^{2}$ statistic is significant at the $5 \%$ ievel suggesting the joint significance of the explanatory variables of the model.

As anticipated, variation in households' WTP is influenced by a combination of socioeconomic and demographic characteristics of respondents. As the estimates show, the coefficient of age of the household head is positive and statistically significant suggesting that as age increases households become more reluctant to pay in any form. More specifically, the variable "age of the head of household" decreases the probability of unwillingness by $4.16 \%$ in comparison to the base category of willingness to pay only in labour.

Contrary to the a priori expectation, education of the household head (EDUC1) increases unwillingness to contribute labour. The reason may be that education raises the opportunity cost of labour time. Additionally, the variable traditional lifestyle' is significant at the $5 \%$ level and increases the probability for households to be unwilling to pay in any form by about $214 \%$. As expected, household size has a strong negative effect on WTP only in cash, suggesting that larger households are more likely to contribute only labour than small households. Education of children in the family (EDUC2) is significantly and positively associated with their parents' WTP for improved solid waste services in cash as well as in cash and labour.

The estimation results also indicate that the wealth variable (WEALTH), as proxied by ownership of a refrigerator, is important in explaining what households would be willing to contribute for solid waste services. More specifically, ownership of a refrigerator is significant at the $10 \%$ level and increases the likelihood payment in cash as well as cash and labour, by $370 \%$ and $400 \%$, respectively. Location of the dwelling unit in relation to road (ROAD) appears to be an important factor in influencing households' decision to pay for improved municipal services. More specifically, distance from road increases households' WTP in cash. Compared to cash, large households are more likely to contribute labour for CV program. From the estimated risk ratio, it can be calculated that household size (HHSZ) is significant at the $10 \%$ level and reduces the likelihood for cash payment by around $20 \%$.

\section{Conclusions and implications}

Household solid waste management has remained a major challenge to the municipal government of Jimma town. One of the main constraints facing the local government in the provision of adequate solid waste collection and disposal services to its citizens 
is the shortage of enough financial and physical resources. Furthermore, private sector investment in solid waste services has been very little (if any) or non-existent at all. Experiences elsewhere demonstrate that local people's participation in planning, financing and monitoring of solid waste management services is one of the main mechanisms to address this gap. However, adequate information has not been available on how to initiate and apply such practices by various municipality governments of Ethiopia including that of Jimma. Therefore, this study has been initiated to get empirical feedback on this issue using a case study from Jimma town, Ethiopia. The main purpose of the study was to identify the key factors influencing households' willingness to pay for improved solid waste services.

This study has provided several interesting outcomes. Firstly, descriptive analysis of the survey data clearly distinguishes four categories of household depending on their responses to the CV question, "Would you be willing to contribute resources for a program that strives to improve household solid waste service? If yes, which resources would you be willing to contribute?" Some households were not willing to pay any resource at all. However, others replied saying that they would like to contribute either only labour or only cash. And, still a group of other households report their willingness to contribute both cash and labour for the proposed program. Thus, policy makers and planners shall be informed that different households are willing to be involved in a program that strives to improve the supply of solid waste services by paying positive resources to the program. Secondly, our estimation results of the MNL regression model indicate that probability payment in any form for improved solid waste services is influenced by economic and non-economic characteristics of the household. Human capital formation and wealth are strongly related to demand for improved solid waste services. Willingness to contribute labour for solid waste is negatively associated with years of schooling and age of the household head. Households' involvement in cattle farming appears to suppress their propensity to raise labour for programs that improve solid waste services. However, it is interesting to note that education of children raises their parents' willingness to pay for improved solid waste services in cash as well as cash and labour. In a similar vein, ownership of a refrigerator increases willingness to pay for improved solid waste services. Additionally, the demand for improved solid waste services is directly correlated with distance from a drivabie road. Thus, planners and policy makers shall give close attention to these evidences to initiate and enhance local people's participation in the provision of improved solid waste services either by the municipality, private sector or some kind of partnership between them. The presence of significant demand for improved solid waste services implies that micro-enterprises for solid waste collection as a low-cost alternative to self-disposal could be organized. Furthermore, the government has to provide assistance for local residents to initiate 
and coordinate their efforts for self-organization of collection and disposal of solid wastes from their premises.

Last but not the least, further research is required to determine the magnitude of resources that could be generated from residents for implementation of improved solid waste services. 


\section{Roforences}

Ahmed, S. A. and Ali, M. 2004. Partnerships for solid waste management in developing countries: linking theories to realities. Habitat International, 28: 467-479.

Aldrich, J.H. and Nelson, F.E. 1984. Linear Probability, Logit and Probit Models. Sage Publications.

Altaf, M. A. and Deshazo, J. R. 1996. Household demand for improved solid waste management: a case study of Gujranwala, Pakistan. Wortd Development, 24(5): 857 868.

Anaman, K. A., Jair, R. M. 2000. Contingent valuation of solid waste collection services for rural households in Brunei Darussalam. The Singapore Economic Review, 45(2): 223 240.

Asrat, P., Belay, K. and Hamito, D. 2004. Determinants of farmers' willingness to pay for soil conservation practices in the Southeastern Highlands of Ethiopia. Land Degradation and Development, 15: 423-438.

Birke, Y. 1999. Solid Waste Management in Ethiopia. $25^{\text {th }}$ WEDC Conference, Addis Ababa, Ethiopia.

Botero, J., Djankov, S., Porta, R.L., De Silanes, F.L. and Shliefer, A. 2003. The Regulation of Labor. NBER Working Paper 9756.

Brockerhoff, M. 1995. Fertility and Family Planning in African Cities: the Impact of Female Migration. Joumal of Biosocial Science, 27(3), 347-358.

Buckley, G., Casale, G. and Fashoyin, T. 2004. Tripartism and Decent Work in Poverty Reduction Strategies in Ethiopia. IFP/Dialogue Paper 5, ILO, Geneva.

Cameron, T. A., Poe, G.L., Ethier, R. G. and Schulze, W. D. 2002. Alternative non-market value-elicitation methods: are the underlying preferences the same? Joumal of Environmental Economics and Management, 44: 391-425.

Carson, R. T. 1997. Contingent valuation: theoretical advances and empirical tests since the NOAA Panel. American Joumal of Agricultural Economics, 79(5): 1501-1507.

Central Statistical Authority (CSA). 1994. Population and Housing Census of Ethiopia, Addis Ababa.

Cointreau-Levine, S. 1994. Private sector participation in municipal solid waste services in developing countries. Urban Management Programme Discussion Paper. No. 13, Washington, DC. The World Bank.

Davis, R. 1963. The value of outdoor recreation: an economic study of the Maine Woods, doctoral dissertation in economics, Harvard University.

Echessah, P. N., Swallow, B. M. Kamara, D. W. and Curry, J. J. 1997. Willingness to contribute labour and money to Tsetse control: application of contingent valuation in Busia District, Kenya. Wonld Development, 25: 239-253.

Greene, W. H. 2000. Econometric Analysis, $4^{\text {th }}$ Edition. New Jersey. Prentice-Hall.

Haab, T. C. and McConnel, K.E. 2002. Valuing Environmental and Natural Resources. The Econometrics of Non-market Valuation. Edward Elgar Publishing Limited, Cheltenham, UK.

Hanemann, W. M. 1984. Welfare evaluations in contingent valuation experiments with discrete responses. American Joumal of Agricultural Economics, 66(3): 332-341. 
Hanley, N. and Spash, C. L. 1993. Cost-Benefit Analysis and the Environment. Edward Elgar Publishing, Inc. Cheltenham, UK.

Harris, J. R. and Todaro, M. P. 1970. Migration, Unemployment and Development: A Theoretical Analysis. American Economic Review 60, 126-142.

Jin, J., Wang, Z. and Ran, S., In Press. Comparison of contingent valuation and choice experiment in solid waste management programs in Macao. Ecological Economics.

Karppinen, $H$. and Harri $H$. 2000. Forest conservation and environmental utilization: public attitudes in Finland. Joumal of Forest Economics, 6(1): 55-80.

Kebede, F. and Mirgissa, K. 1999. Hygienic behaviour and environmental conditions in Jimma Town, South-western Ethiopia. Ethiopian Joumal of Health Development, 13(2): 77 86.

Korfmacher, K. S. 1997. Solid waste collection systems in developing urban areas of South Africa: an overview and case study. Waste Management and Research, 15: 477-494.

Lall, S. V. Deichmann, U., Lundberg, M. K. A. and Chaudhury, N. 2004. Tenure, diversity and commitment: community participation for urban service provision. The Joumal of Development Studies, 40(3): 1-26.

Lauria, D. T. Whittington, D., Choe, C. T. and Abiad, V. 1999. Household Demand for improved sanitation services: A Case Study of Calamba, The Phillippines. In Bateman, I. J. and Willis, K.G. (editors). Valuing Environmental Preferences: Theory and Practice of the Contingent Valuation Method in the US, EU, and Developing Countries. Oxford University Press.

Long, J. S. and Freese, J. 2001. Regression Models for Categorical Dependent Variables Using STATA.

Mulat Demeke, Fantu Guta and Tadele Ferede. 2005. Towards a More Employment-Intensive and Pro-Poor Economic Growth in Ethiopia: Issues and Policies. Addis Ababa, Ethiopia.

Obirih-Opareh, N. and Post, J. 2002. Quality assessment of public and private modes of solid waste collection in Accra, Ghana. Habitat International, 26: 95-112.

Portney, P. R. 1994. The contingent valuation debate: why economists should care? Journal of Economic Perspectives, 8(4): 3-17.

Steel, B. S., List P. and Shindler B. 1994. Conflicting values about Federal Forests: a comparison of national and Oregon Publics. Society and Natural Resources, 7: 137153.

Temesgen, M. and Legesse, W. 2005. Analysis of the type and amount of solid waste generated and adopled disposal methods by the residents of Bonga Town. Ethiopian Joumal of Health Sciences, 15(2): 157-166.

Thapa, G. B. 1998. Lessons learned from solid waste management in Kathmandu, Nepal. Habitat International, 22(2): 97-114.

Todaro, M. P. 1969. A Model of Labor Migration and Urban Unemployment in Less Developing Countries. American Economic Review 59, 138-148.

Train, K. E. 2003. Discrete Choice Methods with Simulation. Cambridge University Press.

Young, R. A. 2005. Determining the Economic Value of Water: Concepts and Methods. Resources for the Future, Washington, DC, USA. 